\title{
Reduced Incidence of Lesser Peachtree Borer and Leucostoma Canker in Peach-Almond Hybrids
}

\author{
G.J. Puterka, R. Scorza, and M.W. Brown \\ Appalachian Fruit Research Station, Agricultural Research Service, U.S. Department of Agriculture, 45 \\ Wiltshire Road, Kearneysville, WV 25430 \\ Additional index words. host resistance, Leucostoma persoonii, Prunus dulcis, Prunus persica, Synanthedon pictipes
}

\begin{abstract}
Damage by lesser Peachtree borer (LPB) (Synanthedon pictipes Grote \& Robinson) and Leucostoma canker that had accumulated during 6 (Orchard A) and 8 (Orchard B) years were compared in peach (Prunus persica L.) and peachalmond [P. amygdalus (Mill.) D. A. Webb] hybrids. Afterward, the main trunk and scaffold limbs of the trees received 10 wounds $26 \mathrm{~mm}$ in diameter and a subset of these trees in Orchard A had wounds inoculated with Leucostoma persoonii Hohn. Before wounding, Leucostoma canker infection and LPB infestations that had accumulated for 6 to 8 years on peach-almond hybrids was $\approx 60 \%$ and $98 \%$ less than on peach in Orchard $A$ and B, respectively. One month after wounding the trees, no significant differences in Leucostoma canker infection and LPB infestations were found among the peach-almond hybrids, treated or not treated with L. persoonii, or untreated peach. Yet, Leucostoma- treated and untreated peach-almond hybrids had 33\% and $25 \%$ less Leucostoma canker and LPB, respectively, when compared with Leucostoma- treated peach. Ten months after wounding, peach-almond hybrids treated with $L$. persoonii still had significantly less Leucostoma canker $(60 \%)$ and LPB $(25 \%)$ when compared with Leucostoma- treated peach. Wound gumming and wound closure rates seemed to influence the degree of LPB infestation and Leucostoma canker. Based on these data, peach-almond hybrids could be valuable sources of resistance to LPB and Leucostoma canker.
\end{abstract}

Lesser Peachtree borer (LPB) is indigenous to the United States, where it is a serious pest of peach and other Prunus spp. Wounds made by farmimplements, disease, cold injury, hail, sunscald, split crotches, or cracked bark are necessary for LPB to initiate an infestation (Reilly et al., 1987). Once entering the wound, LPB feeds on the cambium surrounding the wound. Such feeding eventually can enlarge wounds to the extent that limbs are girdled. Leucostoma canker (formerly Cytospora canker), caused by the fungi Leucostoma persoonii and $L$. cincta (Fr. ex Fr.) Hohn is a major disease of peach. Leucostoma persoonii is the only species known to cause Leucostoma canker in West Virginia (Biggs, 1989). Infection is initiated through injured tissue or cracks in the bark from many causes (cold injured tissue, pruning cuts, leaf scars, shade-weakened twigs), after which gumming cankers form that can girdle limbs and weaken the tree (Willison, 1936). LPB and Leucostoma canker share a close relationship. Leucostoma canker or peach gum from fresh wounds are major ovipositional attractants for LPB (Reed et al., 1988). Moreover, Leucostoma canker predisposes peach trees to LPB attack by producing wounds that are favorable entry sites for LPB larvae (Swift, 1986).

Low degrees of resistance to Leucostoma canker have been found in open-pollinated peach (Chang et al., 1989a, 1989b; Dhanvantari and Dirks, 1983; Scorza and Pusey, 1984). There are no known chemical treatments or cultural methods that can prevent or eliminate Leucostoma canker (Biggs, 1989). Resistance is positively correlated with cold hardiness (Chang et al., 1989b) and rate of suberin formation in wounds (Biggs and Miles 1988). No literature could be found on evaluating Prunus spp. resistance to LPB . In 1991, G.J.P. noted that peach-almond hybrids planted in two peach orchards showed almost no sign of LPB infestation or Leucostoma infection. In this study, we quantified LPB infestations and Leucostoma canker in two orchards containing peach and peach-almond hybrid trees.

Received for publication 19 Oct. 1992. Accepted for publication 9 Apr. 1993. This article reports the results of research only. Mention or use of a trade name or proprietary product does not imply endorsement or recommendation for its use by the U.S. Dept. of Agriculture. The cost of publishing this paper was defrayed in part by the payment of page charges. Under postal regulations, this paper therefore must be hereby marked advertisement solely to indicate this fact.
Materials and Methods

Two orchards containing mixed plantings of peach and peachalmond hybrids were planted in a completely randomized design. Orchard A was a 6-year-old orchard that contained 70 trees and Orchard B was an 8-year-old orchard that contained 225 trees. Both orchards contained peach seedlings that originated from several open-pollinated parents known to be susceptible to Leucostoma canker. Orchard A contained peach-almond hybrids that were segregating $\mathrm{F}$, progeny of a single parentage and Orchard B contained peach-almond hybrids of diverse parentages. The peach-almond hybrids in Orchard A consisted of two distinct phenotypes, almond-like and peach-like, based on the appearance of their leaves, fruit, and bark. Orchard A was subjected to a lowpesticide spray program for disease and insect control, while Orchard B was not sprayed for insects or diseases for 6 years before this study. Tree spacing in Orchard A was $3.5 \mathrm{~m}$ between rows and $2.0 \mathrm{~m}$ within rows, while tree spacing in Orchard B was $4.0 \mathrm{~m}$ between rows and $3.0 \mathrm{~m}$ within rows. These orchards were pruned moderately each year.

The abundance of LPB was monitored using two wing-traps (no. 1C Pherocon; Sentry, Buckeye, Ariz.) baited with pheromone (Century; Sentry) so that wound treatments and evaluations of infestations could be timed properly. LPB infestation and Leucostoma canker in the peach and peach-almond hybrids were quantified on 1 July 1991. Wounds that contained fresh frass from actively feeding LPB larvae or empty pupal cases left behind by LPB adults were considered infested. Leucostoma canker was diagnosed by necrotic wounds that actively flowed dark amber gum, while noncankerous wounds showed little necrosis and flowed clear gum (Swift, 1986). The identity of LPB was confirmed using the morphological characteristics of the mandible described by Stehr (1987). Data for the peach-almond populations were partitioned into peach-like and almond-like hybrids. Afterward, the main trunk and scaffold limbs of peach $(n=36)$, peach-like hybrids $(\mathrm{n}=7)$, and almond-like hybrids $(\mathrm{n}=20)$ received 10 wounds each from a $26-\mathrm{mm}$ hole punch driven through the bark by hammer; then the circular piece of bark that remained was removed. The wound sites had been cleaned with a cloth 
soaked in $70 \%$ ethyl alcohol before being wounded. In Orchard A, randomly chosen subsets of peach $(\mathrm{n}=7)$ and almond-like hybrids $(\mathrm{n}=10)$ had wounds inoculated with $1.0 \mathrm{~g}$ of gum homogenate that contained the causal agent of Leucostoma canker, L. persoonii, using a method described by Swift (1986). The homogenate was made from dark amber gum that was collected from active Leucostoma cankers on 'Redhaven' peach trees. The concentration of $L$. persoonii conidia was $5 \times 10^{5} / \mathrm{ml}$, based on haemocytometer counts taken from a diluted gum sample. The presence of $L$. persoonii in the gum was verified by plating a diluted gum sample on yeast-maltose agar and identifying the pathogen using morphological traits of the colonies as described by Willison (1936).

The number of wounds with active Leucostoma canker, wounds with LPB, wounds with Leucostoma canker and LPB, and degree of gumming were evaluated 1 month after wounding (1 Aug. 1991). Degree of gumming was determined using a 1 to 6 rating

Table 1. Natural damage (evaluated on 1 July 1991) from Leucostoma canker and lesser peachtree borer (LPB) to peach and peach-almond hybrid trees that had accumulated 6 years after planting Orchard $A$ and 8 years after planting Orchard B.

\begin{tabular}{lccc}
\hline & \multicolumn{3}{c}{ Mean no./tree } \\
\cline { 2 - 4 } $\begin{array}{l}\text { Type of } \\
\text { seedling }\end{array}$ & Canker & LPB & $\begin{array}{c}\text { Wounds } \\
\text { (total) }\end{array}$ \\
\hline & Orchard $A$ \\
Peach $(\mathrm{n}=42)$ & $7.3 \mathrm{a}$ & $5.6 \mathrm{a}$ & $7.6 \mathrm{a}$ \\
Peach-like hybrid $(\mathrm{n}=7)$ & $2.5 \mathrm{~b}$ & $1.5 \mathrm{~b}$ & $2.6 \mathrm{~b}$ \\
Almond-like hybrid $(\mathrm{n}=18)$ & $0.5 \mathrm{c}$ & $0.4 \mathrm{~b}$ & $0.6 \mathrm{c}$ \\
LSD $(\alpha \leq 0.05)$ & 1.4 & 1.5 & 1.4 \\
& Orchard $B$ & & \\
Peach $(\mathrm{n}=9)$ & $30.4 \mathrm{a}$ & $15.7 \mathrm{a}$ & $33.6 \mathrm{a}$ \\
Almond-like hybrid $(\mathrm{n}=9)$ & $0.6 \mathrm{~b}$ & $0.1 \mathrm{~b}$ & $0.6 \mathrm{~b}$ \\
LSD $(\alpha \leq 0.05)$ & 19.1 & 8.5 & 18.9 \\
\hline
\end{tabular}

$\overline{\text { PPeach-almond hybrids in Orchard } A \text { were separated into peach- and }}$ almond-like based on the appearance of leaves bark and fruit. Orchard B had only almond-like hybrids.

YTotal number of wounds with or without LPB or Leucostoma canker. system: $1=$ no gumming; 2 to $5=25 \%$ increments of the wound area filled with gum; $6=$ wound area overflowing with gum. Data were taken on the number of LPB infested wounds, wounds with Leucostoma canker, and degree of wound closure in Orchard A 10 months after wounding (12 May 1992). The degree of wound closure was determined by measuring the length of the wound across its horizontal and vertical planes and calculating the area of the wound. Data analyses consisted of analyses of variance (PROC GLM) and treatment means were separated using the least significant difference method (SAS Institute, 1988).

\section{Results}

Peach and peach-almond hybrids were evaluated 1 July 1991, $\approx 3$ weeks after overwintering second-generation LPB adult flight activity had peaked. The frass left by overwintering secondgeneration larvae and empty pupal cases left by the adults that had emerged were most evident at this time. Peach trees in Orchard B had four times as many wounds as those in Orchard A; whereas, peach-almond hybrids in both orchards had nearly the same number of wounds (Table 1). Most of the wounds found on peach and peach-almond hybrids had actively gumming Leucostoma canker. Many of these infected wounds in Orchard A were infested with second-generation LPB larvae, while, in Orchard B, there was a much lower percentage of infected wounds that had LPB. There were substantially fewer LPB infestations and Leucostoma cankers in peach-almond hybrids than in peach in both orchards. In Orchard A, peach-like hybrids had an intermediate number of wounds, Leucostoma canker, and LPB infestations relative to almond-like hybrids and peach.

On 1 Aug. 1991, 1 month after the trees were wounded, peach treated with $L$. persoonii had significantly more wounds with Leucostoma canker than untreated peach in Orchard A (Table 2, Fig. 1). The wounds were evaluated at the peak of first-generation LPB adult flight activity, before they mated and began ovipositing, so that wounds were infested only with first-generation LPB larvae. The number of LPB did not differ significantly between these two treatments for peach. The incidence of wounds that were gumming or had Leucostoma canker, LPB, or Leucostoma canker

Table 2. Mean number of wounds gumming, Leucostoma canker, and lesser peachtree borer (LPB) infestations on 1 Aug. 1991, 1 month following mechanical wounding of peach and peach-almond hybrid trees.

\begin{tabular}{|c|c|c|c|c|c|c|c|}
\hline \multirow[b]{2}{*}{$\begin{array}{l}\text { Type of } \\
\text { seedling }\end{array}$} & \multirow[b]{2}{*}{$\begin{array}{c}\text { Leucostoma } \\
\text { treatment }\end{array}$} & \multirow[b]{2}{*}{$\mathbf{n}$} & \multicolumn{4}{|c|}{ Wounds $^{\mathrm{z}}$} & \multirow[b]{2}{*}{$\begin{array}{c}\text { Gumming } \\
\text { rating }^{x}\end{array}$} \\
\hline & & & Gumming & $\begin{array}{c}\text { With } \\
\text { canker }\end{array}$ & $\begin{array}{c}\text { With } \\
\text { canker } \\
\text { plus LPB }\end{array}$ & $\begin{array}{c}\text { Total } \\
\text { infested } \\
\text { with } \mathrm{LPB}^{\mathrm{y}}\end{array}$ & \\
\hline \multicolumn{8}{|c|}{ Orchard A } \\
\hline \multirow[t]{2}{*}{ Peach } & Yes & 7 & $10.0 \mathrm{a}$ & $9.4 \mathrm{a}$ & $8.9 \mathrm{a}$ & $9.4 \mathrm{a}$ & $5.5 \mathrm{a}$ \\
\hline & No & 29 & $7.3 \mathrm{~b}$ & $6.2 \mathrm{~b}$ & $5.8 \mathrm{ab}$ & $7.7 \mathrm{ab}$ & $5.2 \mathrm{a}$ \\
\hline Peach-like hybrid & No & 7 & $5.7 \mathrm{~b}$ & $5.7 b$ & $4.9 \mathrm{~b}$ & $5.2 \mathrm{~b}$ & $3.7 \mathrm{~b}$ \\
\hline \multirow[t]{2}{*}{ Almond-like hybrid } & Yes & 10 & $6.3 \mathrm{~b}$ & $6.3 \mathbf{b}$ & $5.1 \mathbf{b}$ & $6.3 \mathrm{~b}$ & $2.8 \mathrm{c}$ \\
\hline & No & 10 & $4.5 \mathrm{~b}$ & $4.5 \mathrm{~b}$ & $4.4 \mathrm{~b}$ & $7.3 \mathrm{ab}$ & $3.1 \mathrm{c}$ \\
\hline \multirow[t]{2}{*}{$\operatorname{LSD}(\alpha \leq 0.05)$} & & & 2.9 & 2.9 & 3.0 & 2.8 & 0.8 \\
\hline & & & Orchard $\mathrm{B}$ & & & & \\
\hline Peach - & No & 9 & $8.1 \mathrm{a}$ & $7.9 \mathrm{a}$ & $8.0 \mathrm{a}$ & $9.0 \mathrm{a}$ & $5.0 \mathrm{a}$ \\
\hline Peach-almond hybrid & No & 9 & $3.4 \mathrm{~b}$ & $2.0 \mathrm{~b}$ & $2.0 \mathrm{~b}$ & $6.2 \mathrm{~b}$ & $2.8 \mathrm{~b}$ \\
\hline $\operatorname{LSD}(\alpha \leq 0.05)$ & & & 2.0 & 22 & 1.4 & 1.9 & 0.5 \\
\hline
\end{tabular}

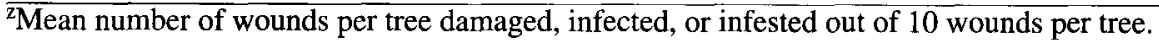

YTotal number of LPB determined by summing the number of LPBs in wounds with canker, gumming without canker, and no gumming.

${ }^{x} 1=$ No gumming; $2=1 \%$ to $25 \%, 3=25 \%$ to $50 \%, 4=50 \%$ to $75 \%$, and $5=75 \%$ to $100 \%$ of the wound filled with gum; 6 $=$ wound overflowing with gum. 


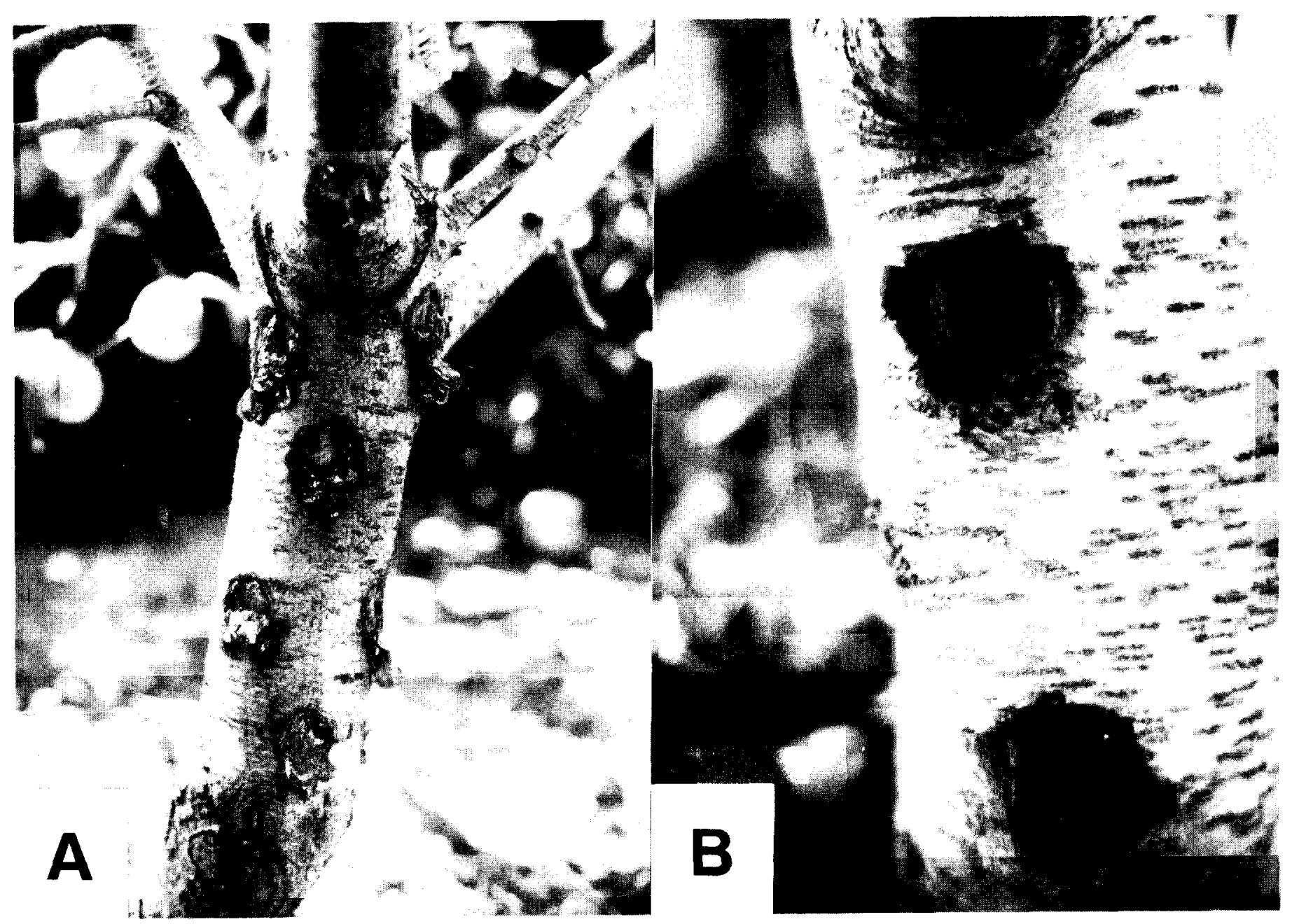

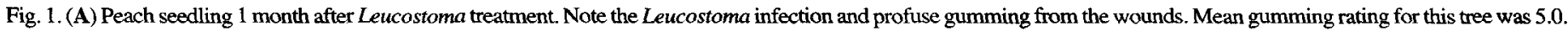
(B) Peach-almond hybrid 1 month after Leucostoma treatment. Note the progressive wound closure and lack of infection. Mean gumming rating for this tree was 1.2 .

plus LPB was similar among the various peach-almond hybrids, treated or not treated with $L$. persoonii, or untreated peach in Orchard A. However, the various peach-almond treatment combinations had significantly fewer wounds that were gumming or had Leucostoma canker, LPB, or Leucostoma canker plus LPB than Leucostoma- treated peach. These significant differences also occurred between the peach-almond hybrids and peach not treated with Leucostoma canker in Orchard B. Gum ratings for peach, treated or not treated with L. persoonii, were significantly higher than for the peach-almond hybrids, either treated or untreated, in both orchards. The almond-like hybrids, whether treated with $L$. persoonii or not, gummed significantly less than the peach-like hybrids in Orchard A.

On 12 May 1992, 10 months after wounding and L. persoonii inoculations, overwintering second-generation LPB larvae had pupated and begun to emerge. Significant differences in LPB infested wounds and canker infections still occurred between peach and the peach-almond hybrids (Table 3). Almond-like hybrids not treated with $L$. persoonii had significantly lower levels of Leucostoma canker than untreated peach, while the level of canker was intermediate in peach-like hybrids. The number of first-generation of LPB in the various peach-almond hybrids also was significantly lower than in peach. The wounds of Leucostoma- treated peach were significantly larger than those of untreated peach. Treated and untreated almond-like hybrids had wound areas that were similar; however, their wound areas were significantly smaller than those of peach treated or not treated with Leucostoma. Wound areas of the untreated peach-like hybrids were similar to those of untreated almond-like hybrids.

\section{Discussion}

The incidence of LPB and Leucostoma canker in both orchards was significantly less in peach-almond hybrids than in peach (Table 1). Before being wounded, almond-like hybrids had $92 \%$ to 98\% fewer open wounds than peach. Most of these wounds appeared to be related to cracks in the bark and limb crotches. Many of these wounds had Leucostoma canker and LPB, although the almond-like hybrids had $92 \%$ to $99 \%$ fewer cankers and LPBs than peach. Our data from mechanically wounding and inoculating the wounds with Leucostomu suggest that the reduced incidence of canker and LPB in peach-almond hybrids has a biological basis (Tables 2 and 3). Peach-like hybrids showed intermediate levels of canker before (Table 1) and after wounding (Table 2), a result indicating that resistance to $L$. persoonii may be associated with almond trans. The size of wound areas suggests that almond-like hybrids are resistant to Leucostoma infection, because the wounds of such hybrids inoculated with Leucostoma closed normally, compared with the untreated control, and closed faster than in peach (Fig. 1). 
Table 3. Degree of lesser peachtree borer (LPB) infestation, Leucostoma canker, and wound area on 12 May 1992, following mechanical wounding on 1 July 1991, Orchard A.

\begin{tabular}{lccccc}
\hline \hline & & \multicolumn{2}{c}{ Wounds $^{\mathrm{z}}$} & \\
\cline { 3 - 5 } $\begin{array}{l}\text { Type of } \\
\text { seedling }\end{array}$ & $\begin{array}{c}\text { Leucostoma } \\
\text { treatment }\end{array}$ & $\mathrm{n}$ & $\begin{array}{c}\text { Infested } \\
\text { with } \\
\text { LPB }\end{array}$ & $\begin{array}{c}\text { With } \\
\text { canker }\end{array}$ & $\begin{array}{c}\text { Wound } \\
\text { area }^{\mathrm{z}}\end{array}$ \\
\hline Peach & No & 29 & $5.6 \mathrm{a}$ & $6.8 \mathrm{a}$ & $503 \mathrm{~b}$ \\
& Yes & 10 & $5.0 \mathrm{a}$ & $6.0 \mathrm{ab}$ & $578 \mathrm{a}$ \\
Almond-like hybrid & Yes & 10 & $2.0 \mathrm{~b}$ & $4.5 \mathrm{bc}$ & $346 \mathrm{~d}$ \\
Peach-like hybrid & No & 8 & $0.3 \mathrm{~b}$ & $1.3 \mathrm{~d}$ & $378 \mathrm{~cd}$ \\
LSD $(\alpha \leq 0.05)$ & No & 7 & $1.6 \mathrm{~b}$ & $4.0 \mathrm{c}$ & $414 \mathrm{c}$ \\
& & & 2.0 & 1.9 & 85 \\
\hline
\end{tabular}

${ }^{\mathrm{z}}$ Mean number out of 10 wounds per tree.

Unlike almonds, which have not been reported to be an LPB host, peach-almond hybrids can serve as hosts but may be less suitable than peach because there are fewer sites (wounds) for oviposition. The strong association between LPB and Leucostoma canker was particularly evident 1 month after the trees were artificially wounded and inoculated with L. persoonii (Table 2). Our study supports other research demonstrating that LPB infestations are largely attributed to Leucostoma canker (Swift, 1986) because infected wounds become perennial cankers that remain open and, thus, provide sites for LPB larvae to enter the tree. Leucostoma canker also has been shown to be a major ovipositional attractant for LPB (Reed et al., 1988). We found that wounds inoculated with Leucostoma gummed 50\% less in almond-like hybrids compared with peach (Table 2), a result suggesting that gumming degree may be an important factor in LPB resistance. Wound closure was greater in peach-almond hybrids than in peach (Table 3), a result suggesting that this could be an another important factor contributing to the reduced LPB infestations and Leucostoma canker.

The low incidence of Leucostoma canker and LPB in peachalmond hybrids before wounding suggests that there were additional factors influencing this damage before our intervention. Distinct physiological and biochemical differences likely exist between peach-almond hybrids and peach. Reduced cold injury has been found to be an important factor related to lower LPB infestations (Smith, 1952). Data on the cold hardiness of peachalmond hybrids is lacking, but Chang et al. (1989b) found one peach-almond hybrid to be more cold hardy and, consequently, have less Leucostoma canker than most peach genotypes. Among the biochemical differences between peach and the hybrids may be two compounds associated with the wound site-prunacin and suberin. Prunacin, a cyanogenic glucoside, is the primary biochemical factor that prevents LPB from attacking uninjured peach bark (Reilly et al., 1987). Suberin, an aliphatic compound with a high phenolic component, creates a physical and biochemical barrier to pathogens, and its accumulation rate at the wound site is correlated to Leucostoma susceptibility in peach (Biggs and Miles, 1988). The role of these compounds in limiting the infestation of LPB and Leucostoma infection in peach-almond hybrids deserves close scrutiny.
Based on our results, peach-almond hybrids could be valuable sources of resistance to LPB and Leucostoma canker. Future research on the inheritance of Leucostoma and LPB resistance, linkage to almond traits, and the mechanism of wound resistance to Leucostoma infection is necessary to determine the value of this resistance.

\section{Literature Cited}

Biggs, A.R. 1989. Integrated approach to control of Leucostoma canker of peach in Ontario. Plant Dis. 73:869-874.

Biggs, A.R. and N.W. Miles. 1988. Association of suberin formation in uninoculated wounds with susceptibility to Leucostoma cincta and $L$. persoonii various peach cultivars. Phytopathology 78:1070-1074.

Chang, L.S., A. Iezzoni, and G. Adams. 1989a. Excised-shoot assay for tolerance of peach to Leucostoma persoonii. HortScience 24:1011-1012. Chang, L.S., A. Iezzoni, G. Adams, and G.S. Howell. 1989b. Leucostoma persoonii tolerance and cold hardiness among diverse peach genotypes. J. Amer. Soc. Hort. Sci. 114:482-485.

Dhanvantari, B.N and V.A. Dirks. 1983. An evaluation of peach cultivars and selections for resistance to Leucostoma cincta. Can. J. Plant Sci. 63:307-310.

Reed, D.K., K.L. Mikolajczak, and C.R. Krause. 1988. Ovipositional behavior of lesser peachtree borer in presence of host-plant volatiles. J. Chem. Ecol. 14:237-252.

Reilly, C.C., C.R. Gentry, and J.R. McVay. 1987. Biochemical evidence for resistance of rootstocks to the Peachtree borer and species separation of peachtree borer and LPB (Lepidoptera: Sesiidae) on peach trees. J. Econ. Entomol. 80:338-343.

SAS Institute. 1988. SAS/STAT user's guide for personal computers. release 6.03. SAS Institute, Cary, N.C.

Scorza, R. and P.L. Pusey. 1984. A wound-freezing inoculation technique for evaluating resistance to Cytospora leucostoma in young peach trees. Phytopathology 74:569-572.

Smith, E.H. 1952. Influence of tree vigor and winter injury on the lesser Peachtree borer. J. Econ. Entomol. 45:607-610.

Stehr, F.W. 1987. Immature insects. Kendall/Hunt Publishing Co., Dubuque, Iowa.

Swift, F.C. 1986. Cytospora canker and the establishment of lesser Peachtree borer (Lepidoptera: Sesiidae) in peach trees. J. Econ. Entomol. 79:537-540.

Willison, R.S. 1936. Peach canker investigations. II. Infection studies. Can. J. Res. 14:27-44. 